\title{
REMOVAL OF NITROGEN, PHOSPHORUS, COPPER AND ZINC FROM SWINE BREEDING WASTE WATER BY BERMUDAGRASS AND CATTAIL IN CONSTRUCTED WETLAND SYSTEMS
}

\author{
RONALDO FIA ${ }^{1}$, REGINA B. VILAS BOAS ${ }^{2}$, ALESSANDRO T. CAMPOS ${ }^{3}$, \\ FÁTIMA R. L. FIA ${ }^{4}$, EDSON G. DE SOUZA ${ }^{5}$
}

\begin{abstract}
This work aimed to study the agronomic performance and capacity of nutrient removal by bermudagrass (Cynodon spp.) and cattail (Typha sp.) when grown in constructed wetlands systems (CWSs) of vertical and horizontal flow, respectively, used in the post-treatment of swine breeding wastewater (ARS). The average yield of dry matter (DM) of bermudagrass in sections of 60-day interval ranged from 14 to $43 \mathrm{t} \mathrm{ha}^{-1}$, while the cultivated cattail produced in a single cut after 200 days of cultivation between 45 and $67 \mathrm{t} \mathrm{ha}^{-1}$ of DM. Bermudagrass extracted up to $17.65 \mathrm{~kg} \mathrm{ha}^{-1} \mathrm{~d}^{-1}$ of nitrogen, $1.76 \mathrm{~kg} \mathrm{ha}^{-1} \mathrm{~d}^{-1}$ of phosphorus, $6.67 \mathrm{~g} \mathrm{ha}^{-1} \mathrm{~d}^{-1}$ of copper and $54.75 \mathrm{~g}$ $\mathrm{ha}^{-1} \mathrm{~d}^{-1}$ of zinc. Cattail extracted up to $5.10 \mathrm{~kg} \mathrm{ha}^{-1} \mathrm{~d}^{-1}$ of nitrogen, $1.07 \mathrm{~kg} \mathrm{ha}^{-1} \mathrm{~d}^{-1}$ of phosphorus, $1.41 \mathrm{~g} \mathrm{ha}^{-1} \mathrm{~d}^{-1}$ of copper and $16.04 \mathrm{~g} \mathrm{ha}^{-1} \mathrm{~d}^{-1}$ of zinc. Cattail and bermudagrass were able to remove, respectively, 5.0 and $4.6 \%$ of the nitrogen and 11.2 and $5.4 \%$ of the phosphorus applied via ARS, being less efficient in extracting $\mathrm{N}$ and $\mathrm{P}$ when the initial intake of these nutrients is evaluated.
\end{abstract}

KEY WORDS: macronutrients, micronutrients, effluent treatment.

\section{REMOÇÃO DE NITROGÊNIO, FÓSFORO, COBRE E ZINCO DE ÁGUAS RESIDUÁRIAS DE SUINOCULTURA POR CAPIM-TIFTON 85 E TABOA EM SISTEMAS ALAGADOS CONSTRUÍDOS}

RESUMO: Este trabalho teve por objetivo estudar o desempenho agronômico e a capacidade de extração de nutrientes pelo capim-tifton 85 (Cynodon spp.) e pela taboa (Typha sp.), quando cultivados em sistemas alagados construídos (SACs) de escoamentos vertical e horizontal, respectivamente, utilizados no pós-tratamento de águas residuárias da suinocultura (ARS). A produtividade média de matéria seca (MS) do capim-tifton 85, em cortes com intervalo de 60 dias, variou entre 14 e $43 \mathrm{t} \mathrm{ha}^{-1}$, enquanto a taboa cultivada produziu em um único corte, após 200 dias de cultivo entre 45 e $67 \mathrm{t} \mathrm{ha}^{-1}$ de MS. O capim-tifton 85 extraiu até 17,65 $\mathrm{kg} \mathrm{ha}^{-1} \mathrm{~d}^{-1}$ de nitrogênio, 1,76 $\mathrm{kg} \mathrm{ha}^{-1} \mathrm{~d}^{-1}$ de fósforo, 6,67 $\mathrm{g} \mathrm{ha}^{-1} \mathrm{~d}^{-1}$ de cobre e 54,75 $\mathrm{g} \mathrm{ha}^{-1} \mathrm{~d}^{-1}$ de zinco. A taboa extraiu até $5,10 \mathrm{~kg}$ ha $\mathrm{d}^{-1}$ de nitrogênio, $1,07 \mathrm{~kg} \mathrm{ha}^{-1} \mathrm{~d}^{-1}$ de fósforo, $1,41 \mathrm{~g} \mathrm{ha}^{-1} \mathrm{~d}^{-1}$ de cobre e $16,04 \mathrm{~g} \mathrm{ha}^{-1} \mathrm{~d}^{-1}$ de zinco. A taboa e o capim-tifton 85 foram capazes de remover, respectivamente, 5,0 e 4,6\% do nitrogênio e 11,2 e 5,4\% do fósforo aplicado via ARS, sendo pouco eficientes na extração de $\mathrm{N}$ e $\mathrm{P}$ quando avaliado o aporte inicial destes nutrientes.

PALAVRAS-CHAVE: macronutrientes, micronutrientes, tratamento de efluentes.

\section{INTRODUCTION}

The swine breeding wastewater (SBW), characterized by high concentrations of organic matter and nutrients (N, P, Cu and Zn), have high polluting power (MATOS et al, 2009; ORRICO JÚNIOR et al., 2010; VIVAN et al., 2010). When improperly discarded in aquatic environments, wastewater with high concentrations of nitrogen and phosphorus can cause eutrophication, resulting from excess of nutrients in the water, allowing the algal blooms that lead to a consequent decrease

\footnotetext{
${ }^{1}$ Eng $^{\circ}$ Agrícola e Ambiental, Prof. Doutor, Departamento de Engenharia, UFLA/Lavras - MG, ronaldofia@deg.ufla.br.

${ }^{2}$ Licenciada em Química, Doutoranda em Recursos Hídricos em Sistemas Agrícolas, Depto. de Engenharia, UFLA/Lavras - MG, regina_lavras@yahoo.com.br.

${ }^{3}$ Eng $^{\circ}$ Agrícola, Prof. Doutor, Departamento de Engenharia, UFLA/Lavras - MG, campos@deg.ufla.br.

${ }^{4}$ Eng $^{\mathrm{a}}$ Agrícola, Prof ${ }^{\mathrm{a}}$. Doutora, Departamento de Engenharia, UFLA/Lavras - MG, fatimarlf@ deg.ufla.br.

${ }^{5}$ Graduando Em Engenharia Ambiental e Sanitária, Depto. de Engenharia, UFLA/Lavras - MG, edsonguilherme7@ @otmail.com.

Recebido pelo Conselho Editorial em: 16-8-2012

Aprovado pelo Conselho Editorial em: 24-8-2013
} 
in quality of the receiving body (ZHANG et al. 2008). Even in small concentrations in the environment, copper and zinc can cause toxicity to aquatic biota. Fish and other aquatic organisms absorb pollutants through the gut, skin and respiratory surfaces (ADA et al., 2012).

The removal of the nutrients and metals present in the ARS is critical to the environmental quality and can be performed in various ways. Among the simple solutions, the adoption of constructed wetlands systems (CWSs) stands out as a feasible and inexpensive way to treat (MATOS et al., 2009; FIA et al., 2011). CWSs are reservoirs filled with porous materials of high hydraulic conductivity, typically consisting of gravel, which support the growth of macrophytes and biofilm development. In this environment the degradation of part of the organic matter in solution is provided, besides the removal by means of physical processes of settleable solids and suspended solids (CHAGAS et al., 2011). CWSs may be classified into three types, according to the flow used: surface, horizontal subsurface and vertical. Each type of flow provides a different degree of interaction of the effluent with the roots, rhizomes and microbial biota.

Among the functions of the macrophytes are: removing nutrients from wastewater, transferring oxygen to the substrate; supporting (rhizomes and roots) for biofilm growth, besides improving the permeability of the substrate and the aesthetics of the environment (KADLEC \& WALLACE 2008). Reports in the literature point to the fact that the absorption of pollutants by vegetation cannot singlehandedly answer for the high efficiencies of pollutant removal (BRAZIL et al., 2007; FIA et al., 2008; FIA, 2009; KANTAWANICHKUL et al., 2009; MATOS et al., 2009; FIA et al., 2011). This fact calls into question the role of macrophytes in these systems, and there is no consensus among researchers about the actual importance of macrophytes in CWSs (Brix, 1997). Even in the face of controversy, MARA (2004), based on data available in the literature, suggests that in cultivated and uncultivated CWSs, removals of organic matter are approximately equal. However, the removal of nitrogen, specifically ammonia nitrogen, is significantly higher in cultivated systems. BRIX (1997), suggest the use of plants in CWSs, but claim that the amount of nutrients extracted is very small compared to applied loads.

On CWSs researched in Brazil, different species have been used: cattail (Typha spp.) (MATOS et al., 2009; SILVA \& ROSTON, 2010), reed (Eleocharis spp.) (MAZZOLA et al., 2005), yellow lily (Hemerocallis flava) (CHAGAS et al., 2011); and grasses such as coastcross grass and bermudagrass (Cynodon spp.) (MATOS et al., 2009). As well as others like alligatorweed (Alternanthera philoxeroides) (FIA et al., 2008; MATOS et al., 2010a) and ryegrass (Loluim multiflorum) (FIA et al., 2010). The combination of vertical wetland flow systems (VWFS) and horizontal subsurface flow systems (HFSs) with different plant species appears to be a viable alternative, according to the different nutrient removal capacities of the plant species. Bermudagrass is an aggressive species, of high nutrient extraction capacity (MATOS et al., 2009; FIA, 2009), and does not require that the soil be constantly saturated with water, enabling cultivation in VFS. Cattail, however, due to the presence of aerenchyma in plant tissue, has greater capacity to translocate oxygen from the aerial part to the root system (KADLEC \& WALLACE, 2008), developing satisfactorily in flooded environments such as HFSs.

Given the above, this work aimed to study the agronomic performance and the extraction capacity of nitrogen, phosphorus, copper and zinc by the species bermudagrass (Cynodon spp) and cattail (Typha $s p$ ) cultivated in constructed wetland systems of vertical and horizontal flow and used in post-treatment of swine breeding wastewater (SBW).

\section{MATERIAL AND METHODS}

The experiment was conducted in the wastewater treatment area of the Department of Animal Science, under the responsibility of the Department of Engineering at the Federal University of Lavras, Minas Gerais, latitude $21^{\circ} 14^{\prime} \mathrm{S}$, longitude $42^{\circ} 00^{\prime} \mathrm{W}$, average altitude of $918 \mathrm{~m}$ and Cwa climate, according to the Köppen classification. 
Currently, swine breeding wastewater (SBW) from a system of full cycle breeding undergoes a pretreatment consisting of static screen and primary / secondary treatment composed of compartmentalized anaerobic reactor (CAR) followed by UASB reactor and decanter (PEREIRA et al., 2011). Therefore, the ARS used in this work was the effluent from the existing treatment system (Table 1).

TABLE 1. Mean values and standard deviation of the hydrogenionic potential $(\mathrm{pH})$, chemical oxygen demand (COD), total Kjeldahl nitrogen (TKN) and total phosphorus (TP) from the swine breeding wastewater used in the experiment.

\begin{tabular}{cccc}
\hline \multirow{2}{*}{$\mathrm{pH}^{(\mathrm{n}=30)}$} & $\mathrm{DQO}^{(\mathrm{n}=29)}$ & $\mathrm{NTK}^{(\mathrm{n}=29)}$ & $\mathrm{PT}^{(\mathrm{n}=27)}$ \\
\cline { 2 - 4 } & & $\mathrm{mg} \mathrm{L}^{-1}$ & $10.6 \pm 8.2$ \\
\hline $8.0 \pm 0.4$ & $379 \pm 146$ & $133 \pm 76$ & \\
\hline
\end{tabular}

$\mathrm{n}-$ number of samples.

The experimental system was comprised of six constructed wetlands (CW). Three with vertical flow (VFS) and three with horizontal subsurface flow (HFSs). The effluent from VFS was the affluent of a HFS. The VFSs were made of fiberglass boxes with a total volume of $100 \mathrm{~L}$, with $0.54 \mathrm{~m}$ high and $0.86 \mathrm{~m}$ in average diameter filled with zero gravel (diameter D-60 $=7.0 \mathrm{~mm}$, and average initial void volume of $0.494 \mathrm{~m}^{3} \mathrm{~m}^{-3}$ ). The HFSs were made of fiberglass boxes with dimensions of $2.0 \mathrm{~m} \times 0.5 \mathrm{~m} \times 0.60 \mathrm{~m}$ (length $\mathrm{x}$ width $\mathrm{x}$ height). The HFSs were filled with zero gravel (diameter D-60 $=7.0 \mathrm{~mm}$ and average initial void volume of $0.494 \mathrm{~m}^{3} \mathrm{~m}^{-3}$ ) to a height of $0.55 \mathrm{~m}$ and the water level was maintained at $0.05 \mathrm{~m}$ below the surface of the support material. In the VFSs the bermudagrass (20 seedlings per $\mathrm{m}^{2}$ ) was cultivated, while the species cultivated in the HFSs was the cattail (Typha sp.) (14 seedlings per $\mathrm{m}^{2}$ ). In this work, bermudagrass was cultivated in VFSs, which presented moisture, but without constant flooding.

The experiment consisted of 3 phases (80, 60 and 60 days) with a gradual increase in superficial application rates (SAR) (Table 2) of organic matter and nutrients to assess the system's ability to adapt to increased loads applied as the removal of these pollutants. The initial load applied to the HFS was in the order of $300 \mathrm{~kg} \mathrm{ha}^{-1} \mathrm{~d}^{-1}$ of COD, as evidenced by MATOS et al. (2010b). The SAR in the VFSs in Phase I was in the order of $800 \mathrm{~kg} \mathrm{ha}^{-1} \mathrm{~d}^{-1}$ of COD, close to the value applied by Sarmento et al. (2012) (about $830 \mathrm{~kg} \mathrm{ha}^{-1} \mathrm{~d}^{-1}$ of COD). The differentiation in the SAR was performed by varying the affluent to the VFSs, which occurred by means of a solenoid flow metering pump, the feeding of the VFSs was performed by gravity from the VFSs. The mean flow in each VFS was equal within each phase. In Phases I, II and III were applied, on average, in each VFS $0.063 \mathrm{~m}^{3} \mathrm{~d}^{-1}, 0.095 \mathrm{~m}^{3} \mathrm{~d}^{-1}$, and $0.129 \mathrm{~m}^{3} \mathrm{~d}^{-1}$, respectively.

ARS samples were collected weekly, after going through the existing anaerobic treatment process and the COD variables were quantified, in closed reflux, total Kjeldahl nitrogen, by the semi-micro Kjeldahl method, total phosphorus by the phosphomolybdic method, and $\mathrm{pH}$ by potentiometry (APHA et al., 2005) in the Water Analysis Laboratory, Department of Engineering UFLA (LAADEG).

Bermudagrass was cut 60, 120, 180 and 200 days after system implantation. Except for the last cut, which occurred due to the end of the experiment, the others were made when the bermudagrass began to flower. Because of the slower development of cattail, it was cut at the end of the experiment, 200 days after its start. The bermudagrass and the cattail were cut at $0.03 \mathrm{~m}$ and $0.10 \mathrm{~m}$ above the level of the support material, respectively. Plant biomass produced was quantified, as well as dry matter after drying at $70{ }^{\circ} \mathrm{C}$ and obtaining constant weight; besides the Nitrogen (N) levels, by the semimicro-Kjeldahl method, phosphorus $(\mathrm{P})$ by spectrophotometry, and Copper $(\mathrm{Cu})$ and Zinc ( $\mathrm{Zn})$ by atomic absorption spectrophotometry after acid digestion, following the methodology described in SILVA (2009) at the Leaf Analysis Laboratory in the Department of Chemistry of UFLA. For nutritional assessment, a representative portion of the total biomass harvested was collected. 
TABLE 2. Average values of surface application rates of organic matter in the form of COD $\left(\mathrm{SAR}_{\mathrm{DQO}}\right)$, of total Kjeldahl nitrogen $\left(\mathrm{SAR}_{\mathrm{NTK}}\right)$ and total phosphorus $\left(\mathrm{SAR}_{\mathrm{PT}}\right)$ from swine breeding wastewaters added in the vertical (VFSs) and horizontal (HFSs) constructed wetland systems in each phase.

\begin{tabular}{|c|c|c|c|c|c|c|c|c|c|}
\hline \multirow{3}{*}{ Systems } & \multicolumn{3}{|c|}{ Phase $\mathrm{I}=80$ days } & \multicolumn{3}{|c|}{ Phase II $=60$ days } & \multicolumn{3}{|c|}{ Phase III $=60$ days } \\
\hline & $\mathrm{SAR}_{(\mathrm{n}=13)}$ & $\operatorname{SAR}_{(\mathrm{n}=12)}^{\mathrm{SAR}_{\mathrm{NTK}}}$ & $\underset{(\mathrm{n}=11)}{\mathrm{SAR}_{\mathrm{PT}}}$ & $\mathrm{SAR}_{(\mathrm{n}=9)}$ & $\underset{(\mathrm{n}=9)}{\mathrm{SAR}_{\mathrm{NTK}}}$ & $\underset{(\mathrm{n}=9)}{\mathrm{SAR}_{\mathrm{PT}}}$ & $\mathrm{SAR}_{(\mathrm{n}=8)}$ & $\underset{(\mathrm{n}=8)}{\mathrm{SAR}_{\mathrm{NTK}}}$ & $\underset{(\mathrm{n}=8)}{\mathrm{SAR}_{\mathrm{PT}}}$ \\
\hline & \multicolumn{9}{|c|}{$\mathrm{kg} \mathrm{ha}^{-1} \mathrm{~d}^{-1}$} \\
\hline $\mathrm{VFS}_{1}$ & 793 & 324 & 22.9 & 828 & 203 & 21.6 & 1,032 & 316 & 30.9 \\
\hline $\mathrm{VFS}_{2}$ & 781 & 321 & 22.5 & 830 & 204 & 21.6 & 1,032 & 316 & 30.9 \\
\hline $\mathrm{VFS}_{3}$ & 793 & 324 & 22.9 & 828 & 203 & 21.6 & 1,032 & 316 & 30.9 \\
\hline $\mathrm{HFS}_{1}$ & 294 & 125 & 8.8 & 319 & 78 & 8.3 & 397 & 121 & 11.9 \\
\hline $\mathrm{HFS}_{2}$ & 290 & 124 & 8.7 & 320 & 78 & 8.3 & 397 & 121 & 11.9 \\
\hline $\mathrm{HFS}_{3}$ & 290 & 124 & 8.7 & 319 & 78 & 8.3 & 397 & 121 & 11.9 \\
\hline
\end{tabular}

$\mathrm{n}$ - number of samples.

A thermohygrograph was installed inside the greenhouse, to measure maximum and minimum air temperature, in addition to relative humidity. Average daily temperatures were obtained by calculating the simple averages between the maximum and minimum daily temperatures (JERSZURKI \& SOUZA, 2010).

Results for bermudagrass were subjected to analysis of variance using the Statistical Program SISVAR $^{\circledR}$ (FERREIRA, 2011) and means were compared by Tukey test at $5 \%$ probability. Statistical evaluation of the nutrients extracted by cattail was not performed because only one cut was made.

\section{RESULTS AND DISCUSSION}

Room temperature in the greenhouse ranged between 14.9 and $36.2{ }^{\circ} \mathrm{C}$, with an average of $25.6^{\circ} \mathrm{C}$, with a maximum quite high compared to the room temperature values for the region of study. The re lative humidity inside the greenhouse varied among the systems monitoring phases (28 to $90 \%$ ). In spite of the high room temperatures, the temperature of the water in treatment varied between 23.5 and $25.7^{\circ} \mathrm{C}$.

Greenhouse coverage changes parameters such as temperature, humidity, wind, radiation balance and energy and, therefore, evapotranspiration. The evaporative demand increases with the reduction of relative humidity. Thus, the drier the air is, the greater the evapotranspiration (DALMAGO et al., 2006), this fact favors the greater uptake of nutrients from the substrate by plants (NUNES et al., 2008), mainly because there is no water retention by the gravel, as might occur with soil.

The $\mathrm{pH}$ values of the ARS in treatment remained slightly above neutral (between 6.9 and 8.1), which can interfere with the availability of some nutrients to the plant species. Usually there is greater availability of calcium and magnesium and unavailability of iron and phosphorus. In $\mathrm{pH}$ values above 8.0 there may be a decrease in nitrogen levels due to ammonia volatilization (SANTOS et al., 2008; ARAÚJO et al., 2012; VIVAN et al., 2010), conditions in which there is a displacement of the chemical balance of ammonium $\left(\mathrm{NH}_{4}{ }^{+}\right)$to ammonia $\left(\mathrm{NH}_{3}\right)$.

\section{Dry matter production}

After implantation of the seedlings there was development, except for the cattail seedlings in the early parts of $\mathrm{HFS}_{2}$ and $\mathrm{HFS}_{3}$. With the continued application of ARS, seedlings planted in $\mathrm{HFS}_{3}$ recovered, while those grown in the early part of $\mathrm{HFS}_{2}$ did not develop. Still, there was no replanting (Figure 1). 

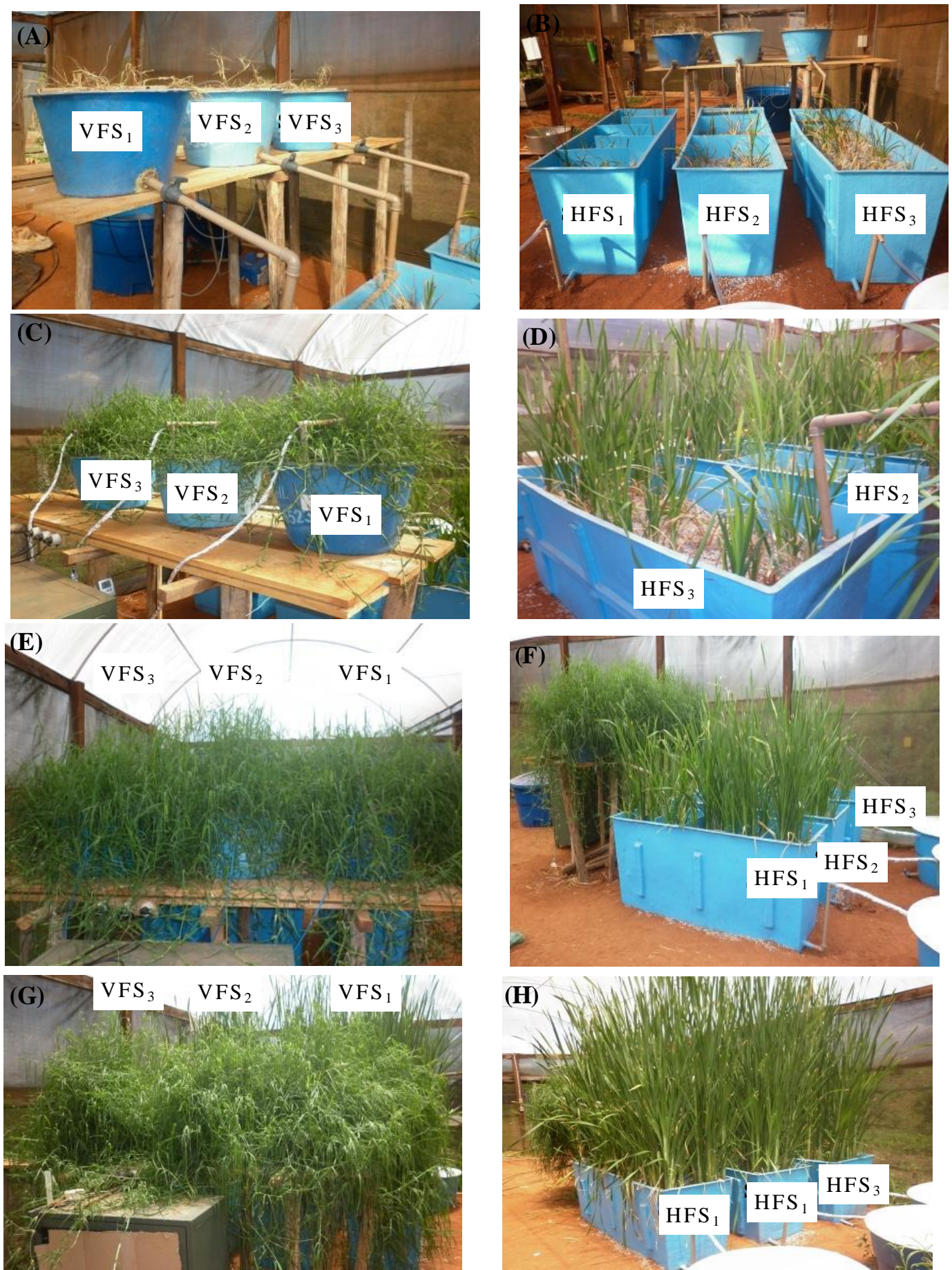

FIGURE 1. Development of bermudagrass implanted in vertical wetland systems (VFSs) and of cattail, implanted in horizontal wetland systems (HFSs) in each monitoring phase: (A) and (B) implantation, (C) and (D) phase I, (E) and (F) phase II, and (G) and (H) phase III.

The productivity of dry matter (DM) increased with the cuts made for bermudagrass (Table 3 ). Lower values observed in cut 1 (14 to $\left.19 \mathrm{t} \mathrm{ha}^{-1} \mathrm{DM}\right)$ are related to the adaptation and development phase of the seedlings. Cut 4 also showed decreased production (6 to $\left.11 \mathrm{t} \mathrm{ha}{ }^{-1} \mathrm{DM}\right)$, which is related to shorter cultivation time. In cuts 1, 2 and 3 cultivation was 60 days, while in cut 4 it was just 20 days, due to the end of the evaluation period. The increase in productivity between cuts 2 and 3 (respectively 28 to 36 and 34 to $43 \mathrm{t} \mathrm{ha}^{-1} \mathrm{MS}$ ) may be due to the increased supply of nutrients between phases II and III (Table 2). Cattail produced between 45 and $67 \mathrm{t} \mathrm{ha}^{-1} \mathrm{DM}$ after 200 days of cultivation. 
TABLE 3. Dry matter yield of bermudagrass shoots collected in the different cuts in vertical wetland systems (VFSs) and of cattail leaves collected in a single cut at the end of the experiment in horizontal wetland systems (HFSs).

\begin{tabular}{|c|c|c|c|c|c|c|}
\hline \multirow{2}{*}{ Systems } & Cut 1 & Cut 2 & Cut 3 & Cut 4 & \multirow{2}{*}{ Systems } & Single cut \\
\hline & \multicolumn{4}{|c|}{$\mathrm{kg} \mathrm{ha}^{-1}$} & & $\mathrm{~kg} \mathrm{ha}^{-1}$ \\
\hline $\mathrm{VFS}_{1}$ & 19,938 & 36,598 & 42,888 & 10,696 & $\mathrm{HFS}_{1}$ & 54,781 \\
\hline $\mathrm{VFS}_{2}$ & 14,250 & 28,434 & 34,312 & 6,882 & $\mathrm{HFS}_{2}$ & 45,489 \\
\hline $\mathrm{VFS}_{3}$ & 18,133 & 32,590 & 34,771 & 6,767 & $\mathrm{HFS}_{3}$ & 67,423 \\
\hline
\end{tabular}

MATOS et al. (2009) found that in the HFSs used to treat ARS between 18 and $28 \mathrm{t} \mathrm{ha}^{-1}$ of dry cattail and 20 and $34 \mathrm{t} \mathrm{ha}^{-1}$ of bermudagrass dry matter were produced in three different cuts, with interval of 100 to 120 days between cuts, and average application of 93 and $22 \mathrm{~kg} \mathrm{ha}^{-1} \mathrm{~d}^{-1}$ of nitrogen and phosphorus, respectively. The lowest yields observed by MATOS et al. (2009) compared to those obtained in this study may be related to the lower TAS of nitrogen applied by these authors. DRUMOND et al. (2006) when applying about $1 \mathrm{~kg} \mathrm{ha}^{-1} \mathrm{~d}^{-1}$ of $\mathrm{N}$ from pig manure on bermudagrass, obtained approximately 6 tons of dry matter in 28-day cycles.

FIA et al. (2011), when evaluating the production of dry matter by bermudagrass and cattail in horizontal wetland systems obtained bermudagrass production between 4 and $7 \mathrm{t} \mathrm{ha}^{-1}$ of dry matter for 60 days cultivation in greenhouse and under organic loads between 160 and $550 \mathrm{~kg} \mathrm{ha}^{-1} \mathrm{~d}^{-1}$ of organic matter in the form of chemical oxygen demand (COD) from the ARS. The lower values observed in this study may be related to the fact that FIA et al. (2011) worked with bermudagrass in HFSs, constantly flooded. As for cattail, FIA et al., (2011) found difficulty in developing and reducing the amount of dry matter produced and systems operation time, reaching the maximum of just over $1 \mathrm{tha}^{-1}$ of dry matter, which was attributed by the authors to the excess of nutrients and not necessarily to the organic load applied.

\section{Nitrogen and phosphorus removal}

The nitrogen concentrations obtained in bermudagrass shoots were about two times higher than the concentration of this nutrient in the cattail leaves. However, for phosphorus higher concentrations were observed in the cattail leaves in relation to those obtained in the bermudagrass shoots (Table 4), except for cut in $4 \mathrm{VFS}_{2}$ and $\mathrm{VFS}_{3}$, in which the plants had not yet shown flowering signals.

FIA et al. (2011) observed higher concentrations of nitrogen and phosphorus in the dry matter of bermudagrass grown in HFSs (4.5 and $0.9 \mathrm{dag} \mathrm{kg}^{-1}$ ). A higher value for nitrogen and similar value for phosphorus in the dry matter of cattail (3.1 and $0.3 \mathrm{dag} \mathrm{kg}^{-1}$ ) were also observed. However, cattail showed greatly reduced growth and limited production of biomass, which may have increased concentration in the cattail leaves. LOURES et al. (2006) and QUEIROZ et al. (2004) found foliar concentrations of phosphorus in bermudagrass, higher than those found in this study, having these authors obtained, respectively, concentrations of $0.46 \mathrm{dag} \mathrm{kg}^{-1}$ and $0.35 \mathrm{dag} \mathrm{kg}^{-}$

${ }^{1}$. However, the crop was on the ground on treatment ramps of domestic sewage and swine breeding wastewater, respectively. 
TABLE 4. Concentration of nitrogen $(\mathrm{N})$ and phosphorus $(\mathrm{P})$ in bermudagrass shoots collected in different cuts in vertical constructed wetland systems (VFSs) and in the cattail leaves collected in a single cut at the end of the experiment in horizontal constructed wetland systems (HFSs).

\begin{tabular}{|c|c|c|c|c|c|c|c|c|c|c|c|}
\hline \multirow{3}{*}{ Systems } & \multicolumn{2}{|c|}{ Cut 1} & \multicolumn{2}{|c|}{ Cut 2} & \multicolumn{2}{|c|}{ Cut 3} & \multicolumn{2}{|c|}{ Cut 4} & \multirow{3}{*}{ Systems } & \multicolumn{2}{|c|}{ Single Cut } \\
\hline & $\mathrm{N}$ & $\mathrm{P}$ & $\mathrm{N}$ & $\mathrm{P}$ & $\mathrm{N}$ & $\mathrm{P}$ & $\mathrm{N}$ & $\mathrm{P}$ & & $\mathrm{N}$ & $\mathrm{P}$ \\
\hline & \multicolumn{8}{|c|}{ dag $\mathrm{kg}^{-1}$} & & \multicolumn{2}{|c|}{ dag $\mathrm{kg}^{-1}$} \\
\hline $\mathrm{VFS}_{1}$ & 3.41 & 0.19 & 3.35 & 0.29 & 2.98 & 0.23 & 3.50 & 0.33 & $\mathrm{HFS}_{1}$ & 1.65 & 0.42 \\
\hline $\mathrm{VFS}_{2}$ & 3.25 & 0.17 & 3.24 & 0.25 & 2.77 & 0.30 & 2.99 & 0.40 & $\mathrm{HFS}_{2}$ & 1.83 & 0.39 \\
\hline $\mathrm{VFS}_{3}$ & 3.48 & 0.27 & 2.89 & 0.27 & 2.73 & 0.33 & 2.93 & 0.41 & $\mathrm{HFS}_{3}$ & 1.96 & 0.35 \\
\hline
\end{tabular}

Cuts $1,2,3$ e $4=60,120,180$ and 200 days after system implantation, respectively.

It should be noted that the extraction of nutrients from wastewater by plants does not happen only according to the concentration of nutrients in the shoots to be removed from the treatment system from the cut, but also in terms of biomass production. To compare the extraction capacity of the species, the daily extraction rate of $\mathrm{N}$ and $\mathrm{P}$ in each system based on the concentration of nutrients in the plant and biomass produced (Table 5) was calculated. Despite this form of presentation of the results, it is evident here that the plant growth rate and nutrient concentration are not constant throughout its growth cycle.

For the bermudagrass it is noted that the extraction of $\mathrm{N}$ was significantly higher $(\mathrm{p}<0.05)$ in the two intermediate cuts. Probably in the first there was influence of the adaptation phase and early development of the seedlings with lower biomass production because leaf concentrations were equal or superior to the other cuts. The average extraction of $\mathrm{N}$ by bermudagrass was 2 to 3 times higher than extraction by cattail. Greater nutrient uptake by bermudagrass compared to cattail was also verified by MATOS et al. (2009).

For phosphorus there was variation between the different cuts and systems. Only the first cut was significantly lower $(\mathrm{p}<0.05)$ than the others (Table 5). Besides the influence of the adaptation phase and early development of seedlings with lower biomass production, the lowest nutrient input in the first phase of the experiment may have contributed to the lower extraction of $P$ in cut 1 . The extraction of $\mathrm{P}$ by cattail was about $70 \%$ of the extraction of bermudagrass in cuts 2,3 and 4 .

TABLE 5. Average extraction values of nitrogen $(\mathrm{N})$ and phosphorus $(\mathrm{P})$ and standard deviation obtained by the averaged values observed in each cut of the vegetation performed for the different vertical (VFSs) and horizontal (HFSs) wetland systems obtained during the experiment.

\begin{tabular}{lcc}
\hline \multicolumn{1}{c}{ Cuts and systems } & $\mathrm{N}$ & $\mathrm{P}$ \\
\cline { 2 - 3 } & \multicolumn{2}{c}{$\mathrm{kg} \mathrm{ha}^{-1} \mathrm{~d}^{-1}$} \\
\hline Cut 1 $\left(\mathrm{VFS}_{1}, \mathrm{VFS}_{2}\right.$ and $\left.\mathrm{VFS}_{3}\right)$ - bermudagrass & $9.86 \pm 1.89 \mathrm{~A}$ & $0.62 \pm 0.21^{\mathrm{a}}$ \\
Cut 2 $\left(\mathrm{VFS}_{1}, \mathrm{VFS}_{2}\right.$ and $\left.\mathrm{VFS}_{3}\right)$ - bermudagrass & $17.16 \pm 2.84 \mathrm{~B}$ & $1.47 \pm 0.29 \mathrm{~B}$ \\
Cut 3 $\left(\mathrm{VFS}_{1}, \mathrm{VFS}_{2}\right.$ and $\left.\mathrm{VFS}_{3}\right)$ - bermudagrass & $17.65 \pm 3.16 \mathrm{~B}$ & $1.76 \pm 0.14 \mathrm{~B}$ \\
Cut 4 $\left(\mathrm{VFS}_{1}, \mathrm{VFS}_{2}\right.$ and $\left.\mathrm{VFS}_{3}\right)$ - bermudagrass & $12.97 \pm 4.98 \mathrm{AB}$ & $1.51 \pm 0.22 \mathrm{~B}$ \\
Single cut $\left(\mathrm{HFS}_{1}, \mathrm{HFS}_{2}\right.$ and $\left.\mathrm{HFS}_{3}\right)-$ cattail & $5.10 \pm 1.32$ & $1.07 \pm 0.16$ \\
\hline
\end{tabular}

For the same variables, means followed by the same capital letter in the column did not differ by the Tukey test at $5 \%$ probability. No statistical evaluation was calculated for cattail because a single cut was performed.

MATOS et al. (2009) found that bermudagrass grown in HFSs used in the treatment of ARS was able to extract different cuts between 5 and $6 \mathrm{~kg} \mathrm{ha}^{-1} \mathrm{~d}^{-1}$ of $\mathrm{N}$ and between 0.7 and $1.2 \mathrm{~kg} \mathrm{ha}^{-1}$ $\mathrm{d}^{-1}$ of $\mathrm{P}$. Lower than the values observed in this study. The authors obtained values close to those obtained for this work for cattail, which was capable of extracting at different cuts between 4 and 5 $\mathrm{kg} \mathrm{ha}^{-1} \mathrm{~d}^{-1}$ of $\mathrm{N}$ and between 0.5 and $1 \mathrm{~kg} \mathrm{ha}^{-1} \mathrm{~d}^{-1}$ of $\mathrm{P}$. 
Based on the contribution of nitrogen and phosphorus to the systems (Table 2) and in the average extraction for all cuts, of nitrogen by bermudagrass and cattail (14.41 and 5.10) and of phosphorus by the two species (1.34 and 1.07), it is verified that the bermudagrass and cattail were able to extract 5.0 and $4.6 \%$ of the nitrogen and 5.4 and $11.2 \%$ of the phosphorus contributed to the systems. MATOS et al. (2009) found that bermudagrass removed on average 5.3 and $3.2 \%$ of $\mathrm{N}$ and $\mathrm{P}$ and cattail 4.5 and $2.3 \%$ of $\mathrm{N}$ and $\mathrm{P}$ contributed to the horizontal systems they evaluated. The values derived in this study were similar to those of N observed by MATOS et al. (2009), but the phosphorus ones were superior. In this work the contributions of $\mathrm{P}$ were close to those applied by MATOS et al. (2009), while N's were 2 to 3 times higher. Thus, different removal rates can be related to different environmental conditions, besides the differences in the pretreatment of ARS. FIA et al. (2011) obtained lower values of nutrient uptake by cattail due to low biomass production (0.8 and $0.05 \mathrm{~kg} \mathrm{ha}^{-1} \mathrm{~d}^{-1}$ of $\mathrm{N}$ and $\left.\mathrm{P}\right)$. As for bermudagrass, values were also lower than those observed in this study, but closer (4.2 and $0.8 \mathrm{~kg} \mathrm{ha}^{-1} \mathrm{~d}^{-1}$ of $\mathrm{N}$ and $\mathrm{P}$ ).

It can be considered that the extractions of $\mathrm{N}$ and $\mathrm{P}$ by cattail and bermudagrass in this work are relatively small when evaluating the total intake of these nutrients, but are close to the values reported in the literature.

\section{Micronutrient removal}

The largest leaf concentrations of copper $(\mathrm{Cu})$ occurred in the second cut of bermudagrass, while the highest concentrations of zinc $(\mathrm{Zn})$ were observed in cut $4 . \mathrm{Cu}$ concentrations in bermudagrass shoots were of the order of 1.5 to 2 times higher than those observed in cattail leaf, while $\mathrm{Zn}$ concentrations were 2 to 3 times higher (Table 6).

TABLE 6. Concentration of copper $(\mathrm{Cu})$ and zinc $(\mathrm{Zn})$ in the bermudagrass shoots collected in different cuts and in cattail leaves collected in a single cut at the end of the experiment.

\begin{tabular}{|c|c|c|c|c|c|c|c|c|c|c|c|}
\hline \multirow{3}{*}{ Systems } & \multicolumn{2}{|c|}{ Cut 1} & \multicolumn{2}{|c|}{ Cut 2} & \multicolumn{2}{|c|}{ Cut 3} & \multicolumn{2}{|c|}{ Cut 4} & \multirow{3}{*}{ Systems } & \multicolumn{2}{|c|}{ Single cut } \\
\hline & $\mathrm{Cu}$ & $\mathrm{Zn}$ & $\mathrm{Cu}$ & $\mathrm{Zn}$ & $\mathrm{Cu}$ & $\mathrm{Zn}$ & $\mathrm{Cu}$ & $\mathrm{Zn}$ & & $\mathrm{Cu}$ & $\mathrm{Zn}$ \\
\hline & \multicolumn{8}{|c|}{$\mathrm{mg} \mathrm{kg}^{-1}$} & & \multicolumn{2}{|c|}{$\mathrm{mg} \mathrm{kg}^{-1}$} \\
\hline $\mathrm{VFS}_{1}$ & 7.0 & 91.9 & 13.9 & 87.1 & 8.8 & 76.6 & 11.3 & 129.3 & $\mathrm{HFS}_{1}$ & 5.4 & 59.3 \\
\hline $\mathrm{VFS}_{2}$ & 7.3 & 88.6 & 12.9 & 90.4 & 13.5 & 113.9 & 11.3 & 133.6 & $\mathrm{HFS}_{2}$ & 5.2 & 40.0 \\
\hline $\mathrm{VFS}_{3}$ & 7.0 & 75.4 & 10.0 & 81.2 & 6.7 & 73.8 & 9.8 & 145.2 & $\mathrm{HFS}_{3}$ & 4.7 & 67.5 \\
\hline
\end{tabular}

Except for the first cut of bermudagrass, in which concentrations in all VFSs were lower, in the other cuts a trend regarding the removal of $\mathrm{Cu}$ and $\mathrm{Zn}$ and applied organic loads was not observed.

FIA et al. (2011) had substantially higher concentrations of $\mathrm{Cu}$ and $\mathrm{Zn}$ than those observed in this work. For bermudagrass concentrations of 113 and $235 \mathrm{mg} \mathrm{kg}^{-1}$ of $\mathrm{Cu}$ and $\mathrm{Zn}$ were observed, and for cattail, 42 and $464 \mathrm{mg} \mathrm{kg}^{-1}$ of dry matter of plants cultivated in HFSs used in the treatment of ARS. SASMAZ et al. (2008), when evaluating cattail plants developed in natural wetland systems which received swage in Turkey obtained foliar concentrations of 30 and $215 \mathrm{mg} \mathrm{kg}^{-1}$ of $\mathrm{Cu}$ and $\mathrm{Zn}$.

Evaluating the extraction capacity of the plant species, it is found in Table 7 that, similarly to nitrogen, extraction of $\mathrm{Cu}$ and $\mathrm{Zn}$ was significantly higher $(\mathrm{p}<0.05)$ in the final cuts of bermudagrass. The extraction capacity of $\mathrm{Cu}$ by cattail was 3 to 4.5 times smaller than for bermudagrass, for $\mathrm{Zn}$ that was 3 to 3.5 times lower, comparing cuts 2, 3 and 4, when there was stability in the development of vegetation. MATOS et al. (2009) found that cattail extracted up to 0.9 and $20 \mathrm{~g} \mathrm{ha}^{-1} \mathrm{~d}^{-1}$ of $\mathrm{Cu}$ and $\mathrm{Zn}$, while bermudagrass up to 0.4 and $57 \mathrm{~g} \mathrm{ha}^{-1} \mathrm{~d}^{-1}$, respectively, in HFSs used in the treatment of ARS. FIA et al. (2011), also in HFSs used in ARS treatment, obtained extractions of the order of 2 and $8 \mathrm{~g} \mathrm{ha}^{-1} \mathrm{~d}^{-1}$ for $\mathrm{Cu}$ and $\mathrm{Zn}$ by cattail, 12 and $21 \mathrm{~g} \mathrm{ha}^{-1} \mathrm{~d}^{-1}$ for bermudagrass. 
TABLE 7. Mean values of copper $(\mathrm{Cu})$ and zinc $(\mathrm{Zn})$ extraction and standard deviation obtained by averaging the values observed in each cut of the vegetation performed for the different wetland systems obtained during the experiment.

\begin{tabular}{lcc}
\hline \multicolumn{1}{c}{ Cuts and systems } & $\mathrm{Cu}$ & $\mathrm{Zn}$ \\
\cline { 2 - 3 } & \multicolumn{2}{c}{$\mathrm{g} \mathrm{ha}^{-1} \mathrm{~d}^{-1}$} \\
\hline Cut 1 $\left(\mathrm{VFS}_{1}, \mathrm{VFS}_{2}\right.$ and $\left.\mathrm{VFS}_{3}\right)$ - bermudagrass & $2.05 \pm 0.30 \mathrm{~A}$ & $24.78 \pm 5.06 \mathrm{~A}$ \\
Cut 2 $\left(\mathrm{VFS}_{1}, \mathrm{VFS}_{2}\right.$ and $\left.\mathrm{VFS}_{3}\right)$ - bermudagrass & $6.67 \pm 1.63 \mathrm{~B}$ & $46.69 \pm 5.60 \mathrm{AB}$ \\
Cut 3 $\left(\mathrm{VFS}_{1}, \mathrm{VFS}_{2}\right.$ and $\left.\mathrm{VFS}_{3}\right)$ - bermudagrass & $5.97 \pm 1.96 \mathrm{~B}$ & $54.22 \pm 11.20 \mathrm{~B}$ \\
Cut 4 $\left(\mathrm{VFS}_{1}, \mathrm{VFS}_{2}\right.$ and $\left.\mathrm{VFS}_{3}\right)$ - bermudagrass & $4.42 \pm 1.42 \mathrm{AB}$ & $54.75 \pm 12.58 \mathrm{~B}$ \\
Single cut $\left(\mathrm{HFS}_{1}, \mathrm{HFS}_{2}\right.$ and $\left.\mathrm{HFS}_{3}\right)-$ cattail & $1.41 \pm 0.21$ & $16.04 \pm 6.82$ \\
\hline
\end{tabular}

For the same variables, means followed by the same capital letter in the column did not differ by the Tukey test at 5\% probability. No statistical evaluation was calculated for cattail because a single cut was performed.

The extraction values observed in this study were similar to those observed by MATOS et al. (2009) and FIA et al. (2011). The extractions are influenced by amounts applied to the systems and by environmental conditions imposed on plants. Thus, even if not evaluating the charge of $\mathrm{Cu}$ and $\mathrm{Zn}$ contributed to the systems, it is believed that the plants may have removed only a small portion of the quantities released in the systems, as shown by MATOS et al. (2009). These authors found that cattail and bermudagrass removed 0.06 and $0.05 \%$ of the $\mathrm{Cu}$ and 2.2 and $3.2 \%$ of the $\mathrm{Zn}$ contributed to the systems.

The biomass produced by bermudagrass could be used as fodder, soil mulch or compost material. In the case of cattail, biomass could be used as soil mulch and compost material. Additionally, systems built on a larger scale could have the plant material cut from both plants used as supply for thermoelectric power generation from biomass.

Given the results presented, it appears that the bermudagrass and cattail grown in VFSs and HFSs were little efficient in extracting $\mathrm{N}$ and $\mathrm{P}$ when evaluated the initial contribution of these nutrients. However, it is believed in the importance of these systems as a post-treatment of the effluent nutrient removal, not only for absorption by plants, but also for the ability to have greater variation in the oxi-reduction potential of the medium (MATOS et al., 2010a) favoring the removal of nutrients, particularly N. Furthermore, the additional removal of organic matter occurs in these systems producing effluents with greater potential for disposal in the environment (HARRINGTON \& SCHOLZ, 2010; SARMENTO et al., 2012).

\section{CONCLUSIONS}

Bermudagrass and cattail have adapted well to wetland systems of vertical and horizontal flow, respectively, used in the treatment of swine breeding wastewater, and to the organic and nutrient loads applied showing good agronomic performance in terms of productivity and nutrient uptake.

The higher extraction capacity of nutrients was presented by bermudagrass compared to cattail, due to higher biomass production. Cattail and bermudagrass were able to remove 5.0 and $4.6 \%$ of nitrogen and 11.2 and $5.4 \%$ of phosphorus contributed to the systems, respectively.

\section{ACKNOWLEDGMENTS}

The authors thank the Foundation for Research Support from the State of Minas Gerais (FAPEMIG) and the National Council for Scientific and Technological Development (CNPq) for providing financial resources and, or, Scientific Initiation scholarships. 


\section{REFERENCES}

ADA, F.B.; AYOTUNDE, E.O.; OFFEM, B.O. Surface and ground waters concentrations of metal elements in central cross river state, Nigeria, and their suitability for fish culture. International Journal of Environment and Sustainability, Olney, v.1, n.2, p.9 - 20, 2012.

APHA; AWWA; WEF. Standard methods for the examination of water and wastewater. $21^{\text {th }}$ ed. Washington, DC: APHA/AWWA/WEF, 2005, [s.n.].

ARAÚJO, I.S. OLIVEIRA, J.L.R.; ALVES, R.G.C.M.; BELLI FILHO, P.; COSTA, REJANE H.R. Avaliação de sistema de tratamento de dejetos suínos instalado no Estado de Santa Catarina. Revista Brasileira de Engenharia Agrícola e Ambiental, Campina Grande, v.16, n.7, p.745-753, 2012.

BRASIL, M.S.; MATOS, A.T.; SOARES, A.A. Plantio e desempenho fenológico da taboa (Typha sp.) utilizada no tratamento de esgoto doméstico em sistema alagado construído. Engenharia Sanitária e Ambiental, Rio de Janeiro, v.12, n.3, p.266-272, 2007.

BRIX, H. Do macrophytes play a role in constructed treatment wetlands? Water Science and Technology, Londres, v.35, n.5, p.11-17, 1997.

CHAGAS, R.C.; MATOS, A.T.; CECON, P.R.; LO MONACO, P.A.V.; FRANÇA, L.G.F. Cinética de remoção de matéria orgânica em sistemas alagados construídos cultivados com lírio amarelo.

Revista Brasileira de Engenharia Agrícola e Ambiental, Campina Grande, v.15, n.11, p.1186-1192, 2011.

DALMAGO, G.A.; HELDWEIN, A.B.; NIED, A.H.; GRIMM, E.L.; PIVETTA, C.R. Evapotranspiração máxima da cultura de pimentão em estufa plástica em função da radiação solar, da temperatura, da umidade relativa e do déficit de saturação do ar. Ciência Rural, Santa Maria, v.36, n.3, p.785-792, 2006.

DRUMOND, L.C.D.; ZANINI, J.R.; AGUIAR, A.P.A.; RODRIGUES, G.P.; FERNANDES, A.L.T. Produção de matéria seca em pastagem de tifton 85 irrigada, com diferentes doses de dejeto líquido de suíno. Engenharia Agrícola, Jaboticabal, v.26, n.2, p.426-433, 2006.

FERREIRA, D.F. Sisvar: a computer statistical analysis system. Ciência e Agrotecnologia, Lavras, MG, v. 35, n.6, p. 1039-1042, 2011.

FIA, F.R.L. Modelos de remoção de matéria orgânica e nutrientes de águas residuárias da suinocultura em sistemas alagados construídos. 2009. 146f. Tese (Doutorado em Engenharia Agrícola) - Universidade Federal de Viçosa, Viçosa, 2009.

FIA, F.R.L. MATOS, A.T.; FIA, R.; LAMBERT, T.F.; MATOS, M.P. Remoção de nutrientes por Typha latifolia e Cynodon spp. cultivadas em sistemas alagados construídos. Revista Ambiente \& Água, Taubaté, v.6, n.1, p. 77-89, 2011.

FIA, R.; MATOS, A.T.; FERREIRA, P.A.; TEODORO, P.E.P.; SCHUERY, F.C.; LUIZ, F.A.R. Desempenho agronômico da Thypha sp. e Alternanthera philoxeroides Mart utilizadas no tratamento de águas residuárias da lavagem e descascamento/despolpa dos frutos do cafeeiro em sistema alagado construído. Engenharia na Agricultura, Viçosa, v.16, n.4, p.436-436, 2008.

FIA, R.; MATOS, A.T.; MATOS, M.P.; ABREU, E.C.; FIA, F.R.L. Tratamento das águas do processamento dos frutos do cafeeiro em filtro anaeróbio seguido por sistema alagado construído: I - remoção de matéria orgânica. Engenharia Agrícola, Jaboticabal, v.30, n.6, p.1191-1202, 2010.

HARRINGTON, C.; SCHOLZ, M. Assessment of pre-digested piggery wastewater treatment operations with surface flow integrated constructed wetland systems. Bioresource Technology, Philadelphia, v.101, n.20, p.7713-7723, 2010.

JERSZURKI, D.; SOUZA, J.L.M. Estimativa da temperatura média diária do ar em distintas regiões brasileiras empregando métodos alternativos. Scientia Agraria, Curitiba, v.11, n.5, p.407416, 2010. 
KADLEC, R.H.; WALLACE, S. D. Treatment Wetlands. Boca Raton: CRC Press, 2008. 1016 p. LOURES, A. P. S.; SOARES, A. A.; MATOS, A. T.; CECON, P. R.; PEREIRA, O. G. Remoção de fósforo em sistema de tratamento de esgoto doméstico, por escoamento superficial. Revista Brasileira de Engenharia Agrícola e Ambiental, Campina Grande, v. 10, n. 3, p.706-714, 2006.

KANTAWANICHKUL, S.; KLADPRASERT, S.; BRIX, H. Treatment of high-strength wastewater in tropical vertical flow constructed wetlands planted with Typha angustifolia and Cyperus involucratus. Ecological Engineering, Amsterdam, v.35, n.2, p.238-247, 2009.

MARA, D. To plant or not to plant? Questions on the role of plants in constructed wetlands. In: INTERNATIONAL CONFERENCE ON WASTE STABILISATION PONDS, 6.; INTERNATIONAL CONFERENCE ON WETLAND SYSTEMS FOR WATER POLLUTION CONTROL, 9., 2004. Avignon: Proceedings... Avignon: IWA/Astee, 2004. CD-ROM.

MATOS, A. T.; FREITAS, W. S.; LO MONACO, P. A. V. Capacidade extratora de diferentes espécies vegetais cultivadas em sistemas alagados utilizados no tratamento de águas residuárias da suinocultura. Revista Ambiente \& Água, Taubaté, v.4, n.2, p.31-45, 2009.

MATOS, A.T.; FREITAS, W.S.; BRASIL, M.S.; BORGES, A.C. Influência da espécie vegetal cultivada nas condições redox de sistemas alagados construídos. Engenharia Agrícola, Jaboticabal, v.30, n.3, p.518-526, 2010a.

MATOS, A.T.; ABRAHÃO, S.S.; BORGES, A.C.; MATOS, M.P. Influência da taxa de carga orgânica no desempenho de sistemas alagados construídos cultivados com forrageiras. Engenharia Sanitária e Ambiental, Rio de Janeiro, v.15, n.1, p.83-92, $2010 \mathrm{~b}$.

MAZZOLA, M.; ROSTON, D.M.; VALENTIM, M.A.A. Uso de leitos cultivados de fluxo vertical por batelada no pós-tratamento de efluente de reator anaeróbio compartimentado. Revista Brasileira de Engenharia Agrícola e Ambiental, Campina Grande, v.9, n.2, p.276-283, 2005.

NUNES, Y.R.F.; FAGUNDES, M.; ALMEIDA, H.S.; VELOSO, M.D.M. Aspectos ecológicos da aroeira (Myracrodruon urundeuva Allemão -Anacardiaceae): fenologia e germinação de sementes. Revista Árvore, Viçosa, MG, v.32, n.2, p.233-243, 2008.

ORRICO JÚNIOR, M.A.P.; ORRICO, A.C.A.; LUCAS JÚNIOR, J. Influência da relação volumoso: concentrado e do tempo de retenção hidráulica sob a biodigestão anaeróbia de dejetos de bovinos. Engenharia Agrícola, Jaboticabal, v.30, n.3, p.386-394, 2010.

PEREIRA, E.L.; CAMPOS, C.M.M.; MOTERANI, F.; OLIVEIRA NETO, A.M. Eficiência de um sistema de reatores anaeróbios no tratamento de efluentes líquidos de suinocultura. Acta Scientiarum. Technology, Maringá, v.33, n.3, p.287-293, 2011.

QUEIROZ, F. M.; MATOS, A. T.; PEREIRA, O. G.; OLIVEIRA, R. A.; LEMOS, A. L. Características químicas do solo e absorção de nutrientes por gramíneas em rampas de tratamento de águas residuárias da suinocultura. Engenharia na Agricultura, Viçosa, MG, v.12, n.2, p.77-90, 2004.

SANTOS, D.R.; GATIBONI, L.C.; KAMINSKI, J. Fatores que afetam a disponibilidade do fósforo e o manejo da adubação fosfatada em solos sob sistema plantio direto. Ciência Rural, Santa Maria, v.38, n.2, 2008.

SARMENTO, A.P.; BORGES, A.C.; MATOS, A.T. Evaluation of vertical-flow constructed wetlands for swine wastewater treatment. Water Air Soil Pollution, New York, v.223, n.3, p.10651071, 2012.

SASMAZ, A.; OBEK, E.; HASAR, H. The accumulation of heavy metals in Typha latifolia L. grown in a stream carrying secondary effluent. Ecological Engineering, Amsterdam, v.33, p.278284, 2008. 
SILVA, E.M.; ROSTON, D.M. Tratamento de efluentes de sala de ordenha de bovinocultura: lagoas de estabilização seguidas de leito cultivado. Engenharia Agrícola, Jaboticabal, v.30, n.1, p.67-73, 2010.

SILVA, F.C. (Ed.). Manual de análises químicas de solos, plantas e fertilizantes. 2. ed. rev. ampl. Brasília: Embrapa Informação Tecnológica, 2009. 627p.

VIVAN, M.; KUNZ, A.; STOLBERG, J.; PERDOMO, C.; TECHIO, V.H. Eficiência da interação biodigestor e lagoas de estabilização na remoção de poluentes em dejetos de suínos. Revista Brasileira de Engenharia Agrícola e Ambiental, Campina grande, v.14, n.3, p.320-325, 2010.

ZHANG, L.; ZHENG, P.; TANG, C.; JIN, R. Anaerobic ammonium oxidation for treatment of ammonium-rich wastewaters. Journal of Zhejiang University Science B, Hangzhou, v.9, n.5, p.416426, 2008. 